\title{
Artistic Value is Attributive Goodness
}

It is common to distinguish between attributive and predicative uses of adjectives. Consider the following:

1. Emma is left-wing

2. Emma is a left-wing Tory

3. James is well mannered

4. James is a well mannered 5-year-old

1 and 3 are predicative uses of 'left-wing' and 'well mannered' respectively, while 2 and 4 are attributive uses. A central way in which attributive uses differ from predicative uses is in what kinds of entailments they license. This thought is captured in two tests for attributive uses of adjectives:

Geach test ${ }^{1}$ : An occurrence of ' $A$ ' is attributive if

' $\mathrm{X}$ is an A B'

doesn't entail ' $\mathrm{X}$ is $\mathrm{A}$ '

(e.g. 'James is a well mannered 5-year-old' doesn't entail 'James is well mannered'. Compare ' $\mathrm{X}$ is a red car, so $\mathrm{X}$ is red')'

Thomson test ${ }^{2}$ : An occurrence of ' $A$ ' is attributive if

' $\mathrm{X}$ is an $\mathrm{AB}$ ', and

' $\mathrm{X}$ is a $\mathrm{C}$ ',

don't jointly entail ' $\mathrm{X}$ is an $\mathrm{A} C$ '

(e.g. 'James is a tall 5-year-old', and 'James is a British citizen' doesn't entail 'James is a tall British citizen'. Compare ' $\mathrm{X}$ is a red car, and $\mathrm{X}$ is an object owned by Sarah, so X is a red object owned by Sarah').

One application of the attributive-predicative distinction that has been of particular interest to philosophers is its application to the term 'good'. Consider the following:

5. Well-being is good

6. Compassion is good

7. That is a good knife

8. You are a good dancer

9. The Tomahawk cruise missile is a good bomb

7-9 are attributive uses of 'good'. They pass both tests for attributive uses. From 'you are a good dancer', and 'you are an accountant', it doesn't follow that you are a good

\footnotetext{
${ }^{1}$ See Geach (1956) 'Good and Evil' Analysis

${ }^{2}$ See Thomson (2008) Normativity, pp. 3-6.
} 
accountant. From 'that is a good knife' and 'that is a birthday present' it doesn't follow that that is a good birthday present. From 'that is a good bomb' and 'that is a thing designed in the 20th Century.', it doesn't follow that that is a good thing designed in the 20th Century. And calling something a good knife, a good bomb, or calling someone a good dancer, does not commit you to saying that thing or person is good.

The attributive-predicative distinction as I've spelled it out is a semantic distinction it's a distinction between two ways of using a term. But philosophers sometimes talk in terms of a corresponding metaphysical distinction: predicative goodness $=$ whatever gets ascribed to something with a predicative use of 'good'; attributive goodness = whatever gets ascribed to something with an attributive use of 'good'. On this way of speaking, predicative goodness is the property of being good, while attributive goodness is the property of being a good $\mathrm{K}$, for some kind $\mathrm{K}$. There are many kinds of attributive goodness - as many, in fact, as there are goodness-fixing kinds: being a good dancer is one kind of attributive goodness, being a good job application is another, and so on. ${ }^{3}$ Since being a good $\mathrm{K}$ does not entail being good, attributive goodness is no guarantee of predicative goodness. And since being a good K and a J doesn't entail being a good J, having one kind of attributive goodness is no guarantee of having another kind.

In this paper I apply the distinction between attributive goodness and predicative goodness in aesthetics - I argue there are good reasons to think that artistic value is a kind of attributive goodness, and that recognising this promises to shed new light on a number of central debates in aesthetics. The paper is organised as follows: in $§ 1$ I say more about the attributive-predicative distinction, and make a case for thinking that artistic value is a form of attributive goodness. In $\$ 2-\S 6$ I show that if artistic value is indeed a form of attributive goodness, there are important consequences. First, it reveals that certain positions about artistic value have a greater burden of proof than ordinarily appreciated. This is the focus in $\S 2$. Second, it reveals that certain popular argumentative moves are fundamentally mistaken. This is the focus in $§ 3-\S 6$.

\section{Preliminaries}

Three further points about the distinction between attributive and predicative goodness. First, it might be tempting to think that attributive goodness is a kind of instrumental goodness. But this would be a mistake. Instrumental goodness is a kind of derivative predicative goodness: goodness that something has in virtue of being a means to something that is good. It's plausible that for many kinds $\mathrm{K}$, good Ks can be instrumentally good - if education is good, then good schools are instrumentally good; if health is good, then good hospitals are instrumentally good. But even if that's right, its not the case that saying of something that it's a good K amounts to saying that it's instrumentally good. Being a good K, doesn't automatically entail being instrumentally

\footnotetext{
${ }^{3}$ The notion of a goodness-fixing kind is Thomson's. See Normativity, p. 21.
} 
good. Something further would need to be the case: namely that there is something of value that a good $\mathrm{K}$ would help to bring about.

Second, some philosophers - most notably Peter Geach and Judith Thomson - hold that there is no such thing as predicative goodness, and that there is only attributive goodness. ${ }^{4}$ It's worth emphasising that this is a pretty radical claim - it's not (just) the denial that anything is good as an end in itself, or that anything is intrinsically good or good all-things-considered. It's the denial that anything ever is good to any degree, or in any respect - accompanied by the proposal that much of what appears to be goodness in some respect, and goodness to some degree, and so on, is really just good-Kness for some $\mathrm{K}^{5}$

In any case, what I argue in this paper is neutral on whether Geach and Thomson are right about there being no predicative goodness. And in fact, if they are right, this would help my arguments, not hinder them. My central claim is that artistic value is not a kind of predicative goodness, but a kind of attributive goodness. If Geach and Thomson are right that there is no predicative goodness, then it would definitely be a mistake to treat artistic value as a kind of predicative goodness.

Third, the turn of phrase 'a good X' does not necessarily guarantee that what is being talked about is attributive goodness, though it is generally a good indicator. One reason for this is that there may be predicative readings of 7-9, but it would take an unusual context for the predicative reading to look like the natural one. Suppose I'm a jaded ex-dancer, and I am complaining about my colleagues in the profession. I tell you, 'all dancers are bad'. And in saying this, I'm not saying they're bad at dancing, I'm saying they're bad, simpliciter. In response, you remind me that there are dancers we both know who are counterexamples - you mention Jenny - 'she's a good dancer,' you say, meaning not to make a claim about her talent at dancing, but to say that she is a dancer and that she is good. That would be a context where the predicative reading looks plausible, but most of the time, the construction 'a good $\mathrm{X}$ ' is a good sign that it's attributive goodness, not predicative goodness, that is at issue.

A further reason is that there may be some kinds $\mathrm{K}$ that are vacuously broad - like 'thing', 'event' 'state of affairs' - where to say that something is a good $\mathrm{K}$ is just to say it is good.

Two points about terminology. First, I will use the phrase 'good simpliciter' and when I want to emphasise that I am talking about predicative goodness. This shouldn't be taken to be referring to only some special kind of predicative goodness - e.g. intrinsic goodness, or final value, or goodness-all-things-considered.

\footnotetext{
${ }^{4}$ Geach (1956); Thomson (2008).

${ }^{5}$ Thomson (2008) talks as though being a good $\mathrm{K}$ is a respect in which something can be good (p. 17). But I think this is misleading. Something can be a good $\mathrm{K}$ without there being any respect in which it is good. A pacifist can, without contradiction, describe something as a good cluster bomb - this doesn't commit her to saying there is any respect in which it is good.
} 
Second, it is common to use the term 'value', and 'valuable' as interchangeable, respectively, with 'goodness' and 'good'. It has recently been argued that valuableness and goodness are distinct, though related, concepts. ${ }^{6}$ There is, nonetheless, a significant current of work in aesthetics and ethics that uses 'value' as a synonym for 'goodness' and 'valuable' as a synonym for 'good', and since I will be engaging with some of that work, I follow that usage here for simplicity.

\section{Why Think Artistic Value is Attributive Goodness?}

Artistic value is intimately related to the concept of a good artwork. People use the phrase 'a good artwork' as interchangeable with 'has high artistic value', and 'increases its artistic value' as interchangeable with 'makes it better art'. The question is, is the 'good' in 'good artwork' being used attributively, or is it like my dancer example above?

The first thing to note is that the construction 'a good $\mathrm{X}$ ' constitutes a presumptive case for thinking that the 'good' here is attributive. Generally, we need a somewhat unusual context to get a predicative reading from a construction of the form 'a good $\mathrm{X}$ ', as with the 'good dancer' example above. So in the absence of arguments for thinking that the 'good' in 'good art' should be read predicatively, we should read it attributively.

While the above alone may be enough, there are, in addition, several considerations that directly support the claim that artistic value is attributive goodness. First, when explaining what they mean by 'artistic value' philosophers typically resort to exactly the kinds of phrases that are standardly used to explain what attributive goodness, as opposed to predicative goodness, amounts to. They say things like:

The value of an artwork as art

Value of an artwork qua art/qua artwork

The value of an artwork considered as art

The value an artwork has when evaluated as art.

Second, if artistic value is attributive goodness this offers a natural explanation for why artistic value can't be had, to any degree, by things that are not artworks.

Third, it also offers a natural explanation for why not every artwork that is a good thing is good art, and why not everything that is good about an artwork increases its artistic value. Harriet Beecher Stowe's Uncle Tom's Cabin played a role in bringing about the abolition of slavery, and that is a good thing about it, but it is at least not obvious that this makes it a better novel. This is exactly what we should expect if artistic value is attributive goodness. Generally, being an X and good is no guarantee of being a good $\mathrm{X}$, and not all good qualities of something that is in fact an $\mathrm{X}$ increase how good an $\mathrm{X}$

\footnotetext{
${ }^{6}$ Grant [unpublished manuscript].
} 
it is. We don't think, for example, that all of the qualities that are good about an object that is in fact a letter-opener, also contribute to its being a good letter-opener; or that all of the qualities that are good about a person who is in fact an athlete, also contribute to her being a good athlete.

In contrast, someone who denied that artistic value was attributive goodness would face a challenge of supplying an alternative explanation of why some good properties of artworks do, and others don't, contribute to their artistic value. This is not to say that the challenge is not meetable, but it is at least not obvious how to meet it, and it's a challenge that those who hold that artistic value is attributive goodness don't face.

\section{What follows if Artistic Value is Attributive Goodness?}

If artistic value is attributive goodness, then some standard ways of talking and thinking about artistic value may need to be re-examined. First, there has been a strong temptation in philosophical aesthetics to think that getting clear on the nature of artistic value will also tell us something about why artworks are important, why they are valuable. Relatedly, an overwhelming number of philosophers who discuss artistic value use the term 'artistic value' as interchangeable with 'the value of art', or with 'the value of an artwork'. ${ }^{7}$ But if artistic value is attributive goodness, it's not so clear that this is right. The question of how valuable a given artwork is is one thing; the question of how good an artwork it is, is another. And the question of how, if at all, these two are linked is a substantive one.

Second, it is extremely common to talk about artistic value as though it is a kind of value. And as though investigating the nature of artistic value is a matter of looking through all the different types of value that artworks can have, and figuring out which one is the artistic one:

A work of art can have many different kinds of value - a cognitive value, a social value, an educational value, a historical value, a sentimental value, an economic value, a therapeutic value; it can possess as many kinds of value as there are points of view from which it can be evaluated. What an artist tries to do is to create a product with a distinctive kind of value. He attempts to make something valuable as art [...] I shall call this value 'artistic value' or the value of a work of art as a work of art. ${ }^{8}$

What would separate a distinctively artistic value from other sorts of value?

\footnotetext{
${ }^{7}$ Dickie (1989), especially the introduction; Sharpe (2000) throughout and esp p. 321; Levinson (1992); Pratt (2012a), (2012b); Shelley (2010)

${ }^{8}$ Budd (1995), p. 1.

${ }^{9}$ Pratt (2012a) p. 591
} 
If there is [..] a properly artistic sort of value [...]. ${ }^{10}$

The practices of making and responding to art are partly defined by the distinctive kind of value to which they are directed: artistic value as opposed to economic, prudential, cognitive, and so on value. ${ }^{11}$

[...] in calling an artwork a good one, we must be attributing some form of value to it, and that this must be a distinctive and special form, properly labeled 'aesthetic'. 12

In the same spirit, philosophers sometimes raise the question of whether artistic value is intrinsic or extrinsic value. ${ }^{13}$ Some go further and talk of artistic value as a kind of value that is somehow distinctive of or unique to art:

[...] a type of aesthetic value that distinguishes artworks at the same time as it provides a criterion for their evaluation ${ }^{14}$

But if artistic value is attributive goodness, there's an important sense in which it's not a kind of value at all. Sure, we can call kinds of attributive goodness 'kinds of value', but in at least one standard use of the term 'value', there's something very odd about saying that for any $\mathrm{K}$, the property of being a good $\mathrm{K}$ is a kind of value. That's because (for at least one standard use of 'value') it's very odd to say that being a good cluster bomb is a kind of value, or that being a good torture method, or a good way to lose friends and alienate people, or a good way to get the economy to spiral into crisis, are kinds of value. If you asked someone to list some things that have value, you wouldn't expect any of the things above to feature on their list!

The lesson from this is that, in at least one standard sense of 'value' attributive goodness is not a kind of value. Something's being a good $\mathrm{K}$ is one thing; its having value is another.

Perhaps it will be objected that even though it's not the case that all forms of attributive goodness are kinds of value, it could still be the case that some forms of attributive goodness are, and maybe artistic value is one such form. But this is a claim that would need to be argued for - it can't just be assumed.

And it might be harder to argue this than it may seem. Accepting the view under consideration would require sacrificing simplicity. A simpler view would say: there are

\footnotetext{
${ }^{10}$ Huddleston (2012)) p. 705

${ }^{11}$ Eldridge (2014), p. 176.

${ }^{12}$ Beardsley (1981) p. lix. See also Lopes (2011).

${ }^{13}$ McGregor (2014), p. 464. See also 'Goldman (2014), p. 95. Stecker (1997), pp. 252-8;

Davies, S. (2006), pp. 188-190; Kieran (2013).

${ }^{14}$ Goldman (2004), p. 95. See also Haskins (2000) p. 2; Beardsley (1981) p. lix.
} 
different kinds of value that things can have. Some of these may contribute to their being good Ks, for some kinds $\mathrm{K}$. But being a good $\mathrm{K}$, for some kind, $\mathrm{K}$, is not a further kind of value they have, on top of whatever other kinds of value they have. The view now under consideration is more complicated: it says that for some kinds $\mathrm{K}$, being a good $\mathrm{K}$ is a further kind of value they have; while for other kinds, $\mathrm{K}^{\prime}$, being a good $\mathrm{K}^{\prime}$ is not a further kind of value they have. Why prefer the more complicated view?

A third, related consequence of artistic value being attributive goodness is that it would supply a new way to argue against the traditional view that artistic value is aesthetic value. Plausibly, aesthetic value is not a kind of attributive goodness - it's a kind of goodness simpliciter. If that's right, then by Leibniz's Law, artistic value cannot be the same thing as aesthetic value. If artistic value is attributive goodness, someone who wants to resist this argument would have to argue that aesthetic value, too, is a kind of attributive goodness.

You might think that these are fairly pedantic points: we ought to refrain from identifying the artistic value of a work with its value, or with some particular kind of value it possesses, such as aesthetic value. But this leaves open that artistic value might nonetheless be intimately related to value, or to some kind of value such as aesthetic value. In 2.1 I suggest that the thesis that artistic value is attributive goodness has striking implications for this issue too.

\subsection{ARTISTIC VALUE AND ITS DETERMINANTS}

For any kind of attributive goodness, you can ask what its determinants are. What features are relevant to how good a tin-opener something is? Or to how good a school something is? If artistic value is attributive goodness, it is no different.

One question we can ask about artistic value's determinants is: must the features that contribute to an artwork's artistic value also contribute to its predicative goodness must they all be good things about it? Call a 'yes' answer to this question the Necessity Claim (NC), because it holds that being a contributor to goodness simpliciter is a necessary condition on being a contributor to artistic value.

\section{Necessity Claim (NC)}

For any quality $\mathrm{Q}$ of an artwork, if $\mathrm{Q}$ is a determinant of its artistic value, Q must be something that contributes positively to its goodness-simpliciter.

$\mathrm{NC}$ can look like a truism. If you're thinking of artistic value as a kind of predicative goodness, then NC can look like it's not only true but too trivially so to even be worth stating. If artistic value is a kind of goodness-simpliciter, then it would follow that anything that contributes to artistic value contributes to goodness-simpliciter. This tendency is helped along by certain ways of talking about artistic value. Talking of artistic value as a kind of value, and using the phrase 'the value of a work of art' as a way of talking 
about its artistic value, can make it very easy to think that the properties that contribute to a work's artistic value must all be values. Relatedly, the widespread practice of calling the determinants of artistic value artistic values makes it sound like a contradiction to say ' $\mathrm{X}$ is an artistic value but is valueless'.

Almost all philosophers who consider the question of what the determinants of artistic value are talk as though they accept the necessity claim. For example, it is common to characterise the project of settling whether something is a determinant of artistic value as a matter of finding out 'whether a value possessed by an artwork is artistic or not'. ${ }^{15}$ Conolly \& Haydar (2001) talk about 'the combination of those values that constitute artistic value'. ${ }^{16}$ George Dickie, in a book-length investigation into the nature of artistic value, begins by identifying what he takes to be an exhaustive list of the possible theories of artistic value. Tellingly, all of them take its determinants to be valuable properties. ${ }^{17}$

But if artistic value is attributive goodness, the necessity claim is not a truism at all, but a substantive claim that cannot be assumed without argument. With attributive goodness in general, it is illegitimate to assume that features that contribute to something's attributive goodness, must be features that make it good simpliciter. Consider how odd it would be to assume that the things that make something a good tin-opener must all be good things, or, worse still, that the things that make something a good weapon, assassination plot, or torture method must be good things.

Defenders of NC might accept this general point about attributive goodness, but maintain that nonetheless, some forms of attributive goodness might be such that the NC holds: there are some kinds $\mathrm{K}$ such that the properties that make something a good $\mathrm{K}$ also make it good simpliciter. ${ }^{18}$ And it might be that art is such a kind. But an argument would be required for this claim; it's not something we can just assume. Since the necessity claim is not in general true of attributive goodness, we should take seriously the possibility that it's not true of artistic value - not just assume it must be true and that it doesn't need argument.

Not only does NC have a burden of proof, there are also reasons to doubt its truth. Critical and appreciative practice suggests the necessity claim is false. Art critics often talk as though disturbingness, and chillingness are positive contributors to artistic value, and it's hard to see why we should take these to be contributors to goodness simpliciter. And some take it to be a mark of great art that it forces us to confront our mortality. But again it is not obvious that this is something good simpliciter about it.

\footnotetext{
${ }^{15}$ Dodd 2014, p. 395

${ }^{16}$ Conolly \& Haydar, p. 123. Emphasis mine

${ }^{17}$ Dickie 1989. See also Goldman (1998), p. 45; Pratt (2012a), pp. 591-592; Stecker (1997a), pp. 260-1; Stecker (2013).

${ }^{18}$ It's plausible, for example, that the qualities that make someone a good friend are qualities that make them good simpliciter to some degree.
} 
So one way in which the thesis that artistic value is attributive goodness would change the landscape in aesthetics is that it would expose $\mathrm{NC}$ as a substantive claim. In the rest of this section I'll suggest that it also reveals that certain standard ways of talking about artistic value also have other substantive assumptions built into them.

First, some ways of talking about artistic value suggest not only NC but also the more obviously implausible converse claim:
Sufficiency Claim (SC):
For any quality $\mathrm{Q}$ of an artwork, if Q contributes positively to its goodness-per- $s e, \mathrm{Q}$ is a determinant of its artistic value. That is, being a contributor to goodness-per-se in an artwork is sufficient for being a contributor to its artistic value.

The tendency to use the phrase 'the value of a work of art' as a way of talking about something's artistic value, for example, can make it sound as though not only NC but also SC holds.

No one explicitly endorses SC. In fact, many explicitly reject it: as discussed in 1.2, it is widely acknowledged that lots of properties can make an artwork good simpliciter, that have no bearing on how good it is as art. ${ }^{19}$ But surprisingly, as I'll suggest in $\S 3$, $\S 4$, and $\S 6$, there has nonetheless been a tendency to unreflectively accept SC. There I will discuss some arguments that are largely taken seriously in aesthetics, that rely on SC. I think it is the failure to keep clearly in mind that artistic value is attributive goodness, helped by the tendency to use 'the value of a work of art' as a way of talking about something's artistic value, that explains why this tacit acceptance of SC has gone unnoticed.

Second, sometimes people talk as though a thesis that I'll call distinctivism holds - that artistic value is determined by a particular kind of value that is only had by art.

Consider again Goldman's claim that artistic value must be '[...] a type of aesthetic value that distinguishes artworks at the same time as it provides a criterion for their evaluation'. ${ }^{20}$ If what I argued above is right, then artistic value is not a type of value at all. But now read Goldman as talking not about artistic value itself, but about its determinants - as saying that artistic value is determined by 'a type of aesthetic value that distinguishes artworks at the same time as it provides a criterion for their evaluation'. Read this way, Goldman would be endorsing distinctivism. He would also be endorsing $\mathrm{NC}$ and aestheticism: the thesis that artistic value is determined only be aesthetic value.

\footnotetext{
${ }^{19}$ See, for example, Stecker (2003), p. 311; Stecker (2005), p. 10; Goldman (2004), p. 95. A recent debate in aesthetics is premised on the falsity of the sufficiency claim. Lopes (2011) asks: since artworks can have valuable properties that are irrelevant to their artistic value, how are we to draw a principled line between the values that contribute to artistic value, and the values that don't? For responses see Huddleston (2012); Dodd (2013), (2014); Stecker (2012); Stecker (2015).
}

${ }^{20}$ Goldman (2004), p. 95. See also Haskins (2000) p. 2; Beardsley (1981) p. lix. 
Even without NC and aestheticism, however, distinctivism is a very strong claim. And if artistic value is attributive goodness, it's not clear why distinctivism should be accepted. We don't in general think that the qualities that make some X a good X must all be qualities that only Xs have. Precision and skill in arguing are plausibly relevant to how good a philosopher someone is, but it would take a peculiarly conceited philosopher to deny that these are skills that many people have who aren't philosophers.

More plausible is what I'll call weak distinctivism: the thesis that the determinants of artistic value must be qualities that in combination are only had by artworks. ${ }^{21}$ But it's not obvious that even weak distinctivism is true. Attributive goodness in general doesn't appear to behave this way. Plausibly, just as there's no reason a non-philosopher can't be precise and skilled in arguing, there's also nothing to stop a nonphilosopher having all the qualities that would make someone who was in fact a philosopher a good philosopher.

It's easy to see why someone who thinks of artistic value as a kind of predicative goodness might be drawn to distinctivism. If you take seriously the thought that only artworks can have artistic value, and you are thinking of artistic value as a kind of predicative goodness, then there is no option but to accept that it's a kind of predicative goodness that only artworks have. But if artistic value is a kind of attributive goodness the motivation for distinctivism is undercut. If artistic value is just goodness as art, there is a clear explanation of why only artworks can have it: only artworks can be good artworks - just as only cars can be good cars.

My point here isn't that distinctivism must be false. Perhaps there are good arguments for distinctivism. My point is just that arguments would need to be given: it shouldn't be accepted as so obviously true as not to require argument.

In $\S 1$ I argued that artistic value is attributive goodness. In this section I've suggested that if this is correct, it is has some striking consequences: it promises to shift the terms of certain debates about artistic value. Theses about the determinants of artistic value that have enjoyed the status of truisms - most notably the necessity claim would in fact stand in need of argument. And others, such as distinctivism, are less well-motivated than they initially appear. In Sections 3-6 I discuss in detail three further debates in which the recognition that artistic value is attributive goodness promises to shed important light.

\footnotetext{
${ }^{21}$ Berys Gaut considers the possibility of weak distinctivism in Gaut (2007), p. 172. Conolly \& Haydar (2001) appear to endorse weak distinctivism, p. 123.
} 


\section{Empiricism and Instrumentalism}

A popular view is that the artistic value of an artwork is determined by the value of the experience it occasions in observers who understand the work. ${ }^{22}$ Call this view empiricism about artistic value. A popular objection to empiricism is that it renders artworks replaceable by anything that is capable of providing the (qualitatively) same experience. The thought is that if you think that what matters about an artwork is the experience it provides, then this looks to commit you to saying that if one could get that same experience from a drug, or from being hooked up to a Nozickian experience machine, then nothing important would be lost by replacing the artwork with the drug, or the machine. Call this the replaceability objection.

The Replaceability Objection:

1. If empiricism (or instrumentalism, more broadly) is true, then the determinants of a work's artistic value are properties that something other than the work can have. (Premise)

2. If the determinants of a work's artistic value are properties that something other than the work can have, then the work is (in principle) replaceable without loss of value. (Premise)

3. Artworks are not replaceable without loss of value. (Premise)

4. So the determinants of artistic value cannot be properties that something other than the work can have (Modus Tollens, from 2, 3)

5. So instrumentalism is false (Modus Tollens, from 1, 4)

In fact, the replaceability objection is taken to threaten not just empiricism, but any theory that takes the artistic value of a work to be determined by some instrumental value that it has - such as cognitive value, or 'refining moral feeling or raising political consciousness', ${ }^{23}$ or some combination thereof.

Most people take the replaceability objection seriously. Empiricists, and instrumentalists more broadly, treat it as a challenge to which they must have something to say, and their opponents tend to use it as the central pillar of a conclusive argument against them. ${ }^{24}$

Those who dispute the argument tend to focus their efforts on disputing premise 1, although some have contested premise $3 .^{25}$ To my knowledge, no one takes issue with premise 2. But if artistic value is attributive goodness, premise 2 is highly dubious. I

\footnotetext{
${ }^{22}$ See, for example, Budd (1995); Graham (2006). For critical discussion of the view, see Sharpe (2000); Shelley (2010).

${ }^{23}$ These examples come from Haskins (2000), p. 2.

${ }^{24}$ See Haskins (2000); Kieran (2013); Conolly \& Haydar (2001), p. 123; Sharpe (2000); Levinson (1992), pp. 303-4; Shelley (2010); Budd (1980), pp. 39-41; (1985), pp 123-4; (1995), pp. 13-16; Graham 1997, p. 56; Davies, D. (2005), p. 25; Goldman (1998) pp. 4-5.

${ }^{25}$ Stecker (1997a): pp. 252-258.
} 
think that the reason 2 has been taken to be innocuous is that it appears at first blush to be an instance of the following plausible principle:

Value Replaceabilty (VR): If the properties in virtue of which an object $\mathrm{O}$ i $\mathrm{s}$ valuable are properties that something other than $\mathrm{O}$ could have, then $\mathrm{O}$ is in principle replaceable without loss of value.

But if artistic value is attributive goodness, then VR lends no support to 2 . VR is a principle concerning predicative goodness. To assume that Premise 2 follows from VR would be to assume the Sufficiency Claim, that every quality that contributes to a work's goodness simpliciter must also contribute to its artistic value. But as I argued in Section 2 (and as pretty much everyone in fact acknowledges) the sufficiency claim is false. Artworks can have properties that make them valuable but do not bear on their artistic value. But if this is right, then even if all the properties that bear on a given artwork's artistic value can be had by other things, it doesn't follow that all the properties that make it valuable can be had by other things. And so empiricists (and instrumentalists more broadly) incur no commitment to saying that the work is replaceable without loss of value. As it stands, then, the replaceability objection is unconvincing, even if 1 and 3 are true. At the very least, those who make the replaceability objection, would need to supply an alternative argument for Premise 2.

This is good news for artistic empiricists, but the recognition that artistic value is attributive goodness isn't an unequivocal good for artistic empiricists. As I argue in the next section, a major advantage that empiricists claim for their theory is also illusory, if artistic value is attributive goodness.

\section{The Explanatory Advantage Argument for Empiricism}

Philosophers sometimes suggest that an advantage of empiricism is that empiricists can supply an answer to the question of why the things they take to be determinative of artistic value are valuable. James Shelley, for example, puts the point as follows:

Suppose [a non-empiricist] is asked to explain the value of the Allegro of Mozart's Twenty-Ninth. She will reply [...] that it is valuable in virtue of some subset of its properties [...]. But just what makes just these properties valuable? The empiricist has an answer. ${ }^{26}$

Call this the explanatory advantage argument for empiricism. The thought is that the empiricist can say that the work is valuable in virtue of the fact that it gives rise to a valuable experience: the work's value is explained in terms of the value of the experi-

\footnotetext{
${ }^{26}$ Shelley (2010), p. 715. Although Shelley rejects empiricism he takes this argument seriously. His view is that empiricism does have an advantage in this respect, but that it is outweighed by significant disadvantages that it has (most notably its vulnerability to the replaceability objection, discussed above).
} 
ence the work is capable of providing. And that the properties that contribute to a work's artistic value are valuable in virtue of the fact that these are the properties that ground the work's capacity to provide this valuable experience. Those who reject empiricism, so the argument goes, are at a prima facie disadvantage in that it's not clear that they can offer any explanation of the value of the work.

The argument rests on a mistake, however. If artistic value is attributive goodness, there is no need to explain what makes these properties valuable. Nor even to explain what makes it the case that these properties make objects that have them valuable. Unless the necessity claim is true, there is no requirement to say that the properties that make something good art are properties that make something good simpliciter. So if empiricism does explain why the properties that make something good art make it good simpliciter, it's not clear that this gives empiricism any kind of advantage. In fact, it may be a disadvantage, in that it amounts to a commitment to the necessity claim: if its rivals don't incur such a commitment, this looks like a prima facie reason to prefer them. ${ }^{27}$

Perhaps a defender of empiricism might respond with a modified explanatory advantage argument: that the empiricist can explain what makes these properties the determinants of artistic value. Empiricism, according to this argument, is able to say something more explanatory than rival theories because it can answer not only question (i) but also (ii):

(i) What are the determinants of artistic value?

(ii) Why are they the determinants of artistic value?

But this, too, is mistaken. Empiricism doesn't offer any kind of an answer to (ii). It might look initially as though empiricism says that the answer to (i) is: 'the experience the work affords', and that the answer to (ii) is: 'because that experience is valuable'. But if artistic value is attributive goodness, the (ii) answer is no answer at all. The fact that some feature of an artwork is valuable is no guarantee that it'll be in any way relevant to artistic value. To assume otherwise would be to assume the sufficiency claim.

Perhaps its true that non-empiricist approaches always only answered (i), but now we've seen that empiricism only answers (i) too. So this is no point of contrast between the rival theories, and so no reason to prefer empiricism to its rivals. If artistic value is attributive goodness, then, the apparent explanatory advantage of empiricism over rival theories disappears.

\footnotetext{
27 You might think that if empiricists can explain why the properties that make something good art are good simpliciter, this wouldn't commit them to the Necessity Claim, but only to the weaker claim that all the properties that make something good art are as a matter of fact properties that make it good simpliciter, although this might not hold necessarily. But the same considerations apply here. Namely, it's not clear why this should be taken to be a neutral datum that needs to be explained, and hence an advantage for empiricsts, rather than a commitment that empiricists incur, and which its rivals do not.
} 


\section{Realism}

Some philosophers are attracted to a view that I will call value-scepticism. Valuescepticism holds that there are no values - if we drew up a list of all the things that exist, whatever else it contained, it would not contain values. Value-scepticism constitutes a popular motivation for rejecting realism about morality, and about beauty. ${ }^{28}$ The argument would go like this:

P1. Moral realism holds that moral goodness genuinely exists

$\mathrm{P} 2$. Moral goodness is a value

P3. There are no values (value-scepticism)

C. Moral realism is false

$\mathrm{P} 1 *$. Realism about beauty holds that beauty genuinely exists

$\mathrm{P} 2 *$. Beauty is a value

P3*. There are no values (value-scepticism)

$\mathrm{C}^{*}$. Realism about beauty is false

P1-2 together amount to the claim that moral realism is committed to the existence of values. $\mathrm{P} 1{ }_{-} 2 *$ together amount to the claim that realism about beauty is committed to the existence of values. Add to either of these the value-scepticism claim, that there are no values, and you have an argument against realism of the relevant kind.

It is sometimes assumed that the same kind of argument can be made against realism about artistic value. ${ }^{29}$ However, if artistic value is attributive goodness, as I have argued, such an argument would be unsuccessful. Value-sceptics, while they may deny that anything can really be morally good or beautiful, do not have to deny that something can be a good X. They can accept that there can be good job applications, good bombs, good tin-openers, and so on. They just have to deny that any part of what makes something a good job application, good tin-opener, etc. is its possession of some kind of metaphysically dubious value. And this is not especially hard for the value-sceptic to do. After all, we already accept that for some Xs, being a good X is compatible with a complete lack of goodness of the kind that worries the value-sceptic. Plausibly, no part of calling something a good bomb, for example, involves committing to its being good in any respect.

So if artistic value is attributive goodness, there is no straightforward route from value-scepticism to antirealism about artistic value. Unlike realism about beauty and moral goodness, realism about artistic value does not straightforwardly incur metaphysical commitments that the value-sceptic has to reject.

${ }^{28}$ See Mackie, J L (1977) Ethics: Inventing Right and Wrong (London: Penguin) Olson 2014 Moral Error Theory OUP; Streumer, B. (2013) 'Can we believe the Error Theory?' Journal of Philosophy; Streumer, B. forthcoming Unbelievable Error OUP.

${ }^{29}$ See, for example, Davies (2006), p. 32; Railton (1998); Bender (2003), p. 87; Goldman (1993); Pratt (2012a), pp. 592-3; Eldridge (2014), pp. 170-171. 
One might object, however, that even if there is no straightforward route from valuescepticism to antirealism about artistic value, there might still be a route of sorts. Value-scepticism does not entail antirealism about artistic value on its own, but in conjunction with the plausible thesis that at least some of the determinants of artistic value are values, it would. Most people think that beauty is a determinant of artistic value, for example. And beauty looks like a value.

But this argument is unconvincing. It's only plausible that some of artistic value's determinants are values if value-scepticism is false. If value-scepticism is true, then this would undermine the thesis that artistic value has values among its determinants. Value-sceptics should either deny that beauty features on the list of determinants of artistic value (on the grounds that it doesn't exist), or deny that beauty is a value.

There isn't any obvious reason, then, to think that value-sceptics ought to be antirealists about artistic value. Similar considerations apply to what I'll call moderate valuescepticism: the view that there are no mind-independent values. The moderate valuesceptic can accept that there are values, as long as she holds that they are mind-dependent.

Moderate value-scepticism supplies a motivation for rejecting robust realism about moral goodness and beauty, where robust realism about beauty/moral goodness is the thesis that beauty/moral goodness is mind-independent. The arguments would go like this:

P1. Robust moral realism holds that moral goodness exists and is mindindependent

$\mathrm{P} 2$. Moral goodness is a value

P3. There are no mind-independent values

C. Robust moral realism is false

P1*. Robust realism about beauty holds that beauty exists and is mindindependent

$\mathrm{P} 2 *$. Beauty is a value

P3*. There are no mind-independent values

C. Robust realism about beauty is false

P1-2 together amount to the claim that robust moral realism is committed to the existence of mind-independent values. Add to these the moderate value-scepticism claim in P3, that no such values exist, and you have an argument against moral realism. P12 together amount to the claim that robust realism about beauty is committed to the existence of mind-independent values. Add to these the moderate value-scepticism claim in P3, that no such values exist, and you have an argument against robust realism about beauty.

Moderate value-scepticism might be thought to also supply a motivation for rejecting robust realism about artistic value in the same way as the arguments above about 
moral goodness and beauty. ${ }^{30}$ However, if artistic value is attributive goodness, such an argument would be unsuccessful. If artistic value is attributive goodness, there is no pressure - without further premises - to think that committing to the existence and mind-independence of artistic value is to commit to anything the moderate valuesceptic is uncomfortable with. In general, to say that it is a mind-independent matter whether something is a good $\mathrm{X}$, is not to commit to the existence of mind-independent values. This is because, as we saw above, something can be a good X even if there are no values. It follows from this that it can be mind-independent whether something is a good $\mathrm{X}$ even if there are no mind-independent values.

There may nonetheless be $a$ route from moderate value scepticism to the mind-dependence of artistic value but it wouldn't be as direct as the arguments above. It is plausible that if any of the determinants of artistic value is mind-dependent, then artistic value itself would have to also be mind-dependent. If we further assume that artistic value has values among its determinants, then we could argue as follows:

P1. Artistic value has values among its determinants

P2. Values are mind-dependent

P3. If artistic value has any mind-dependent determinants, it is minddependent

C. So artistic value is mind-dependent.

In any case, however, the argument from moderate value-scepticism against robust realism about artistic value is importantly different from the arguments moderate value-scepticism generates against robust moral realism and robust realism about beauty since, crucially, it relies on further premises.

\section{Defining Art}

Some theories define art in terms of qualities about artworks that are valuable. Call definitions that have this feature value-definitions. The definitions of art proposed by $\mathrm{R}$ G Collingwood and by Clive Bell are examples (at least if clarifying and expressing emotions and having significant form, respectively, are good things).

It is widely taken to be a knock-down objection to value-definitions that they cannot accommodate bad art. George Dickie, for example, argues that 'If works of art are defined as necessarily valuable, it would make it difficult or impossible to speak of bad or worthless art.' 31 There have been a number of ingenious suggestions for how value-definitions can deal with the objection. Stephen Davies suggests that proponents of value-definitions could say that bad art is only bad relative to other art - it's good really, but it can still be bad compared to other art. Just as someone who is tall really

\footnotetext{
${ }^{30}$ Pratt (2012a), p. 592-3.

${ }^{31}$ Dickie (2000), p. 97. See also Stecker (2005), p. 83; Pratt (2012b), p. 148; S. Davies (2007), pp. 32-33; Wieand (1981).
} 
can still be a short basketball player, an artwork can be good but still bad art. ${ }^{32}$ Henry Pratt suggests distinguishing two kinds of artistic value. ${ }^{33}$

But if artistic value is attributive goodness, the worry about value-definitions is incorrect, and the clever defensive moves are unnecessary. There is no tension to be resolved between value-definitions and the observation that some art is bad art. Attributive badness is entirely compatible with goodness simpliciter (something can be good in some way, while still being a bad X): a person can be good and a bad dancer, and a turn of events that is good might be bad dinner party anecdote material (too boring). So if the 'bad' in 'bad art' is used attributively, then there is room in principle for something that is a bad artwork to be good simpliciter. ${ }^{34}$

To put it another way: if the sufficiency claim is false (which, as we've seen, most people accept it is), then not all valuable things about an artwork are determinants of its artistic value. So a guarantee that all artworks have some value is not a guarantee that all artworks are good art, or indeed that they have any degree of artistic value.

To be sure, there are definitions of art that cannot allow for bad art, and very often these theories happen to be value-definitions. The definitions of art proposed by Collingwood and Bell are examples. But it's not because they are value-definitions that they can't allow for bad art: rather, it's because of a distinct and entirely separable feature they happen to have. Namely, the fact that they take the quality in terms of which they define art, to be the sole determinant of artistic value. Call this the defini-

\footnotetext{
${ }^{32}$ Davies, S. (2007), p. 32.

${ }^{33}$ Pratt (2012b)

${ }^{34}$ You might think: Davies's suggestion that an artwork can be good but still bad art by being good but still bad compared to other art, is a way of acknowledging that artistic value is attributive goodness. But this is not quite right. One way in which an adjective can be attributive is in the way that 'tall' is. Being a tall $\mathrm{K}$ is different from being tall, because being a tall $\mathrm{K}$ is just being tall relative to Ks. Call attributive adjectives of this kind Comparison Class Attributives (CCAs)
}

When ' $\mathrm{J}$ ' is a Comparison Class Attributive, the reason something can be $\mathrm{J}$ and be a $\mathrm{K}$, without being a $\mathrm{J} \mathrm{K}$, is because the kind $\mathrm{K}$ in question can set the bar for J-ness particularly high. But CCAs are not the only kind of attributive adjective out there. Consider 'famous'. 'Famous' has attributive and predicative uses. Someone can be a famous politician, a famous tennis player, and they can be just famous full stop. But now consider: someone can be famous, and play chess, without being a famous chess player. Is that because chess players are all so famous that they set a particularly high standard for fame? No!

Moreover, 'good' when used attributively, doesn't appear to behave like a CCA. Rather, 'good' looks more like 'famous' in this respect. A person can be good, and a bad dancer, and that's not a matter of being bad simpliciter compared to other dancers. 
tion-evaluation parallelism. ${ }^{35}$ For Collingwood it's the expression and clarification of emotion that both secures art-status and determines artistic value, and for Bell it's the having of significant form (and the corresponding production of the aesthetic emotion).

It's the definition-evaluation parallelism that renders Bell's and Collingwood's theories unable to accommodate bad art. If one and the same quality is both criterial of artstatus and determinative of artistic value, as definition-evaluation parallelism ensures, there cannot be any bad art, since the thing that would need to be lacking for the art to be bad art, is also the very thing that no art can lack.

Some philosophers suggest that definitions of art that have the definition-evaluation parallelism have the advantage that they shed light on the question of why art is valuable:

Some people regard the concept of art as essentially evaluative. Tolstoy was one such. Only good art qualifies as art, he thought. [...] By this approach, defining art and analysing what makes art valuable are related like the sides of a coin. $^{36}$

But this also is based on conflating the definition-evaluation parallelism with property of being value-definition. If artistic value is attributive goodness, then theories with the definition-evaluation parallelism tell us something about what makes art good art, but (unless the equivalence thesis holds) there is no guarantee they'll tell us about what makes art valuable.

Consider how odd it would be to apply this line of reasoning for other kinds of attributive goodness:

Some people regard the concept of an assassin as essentially evaluative.

Only good assassins qualify as assassins, [according to this view] [...] By this approach, defining assassins and analysing what makes assassins valu able are related like the sides of a coin.

The reasoning is clearly faulty. From the supposition that only good assassins qualify as assassins, it wouldn't follow that there is anything good or valuable about assas-

\footnotetext{
${ }^{35}$ I've said that very often the two features (being a value-definition, and having the definition-evaluation parallelism) go together. In fact, it might be that historically they have always gone together. It's hard to find examples of definitions of art that have one of these two features without the other. But if so, this is a further interesting consequence of artistic value's being attributive goodness: it reveals that there is space for the two to come apart, where previously they had looked to be inseparable, and perhaps even equivalent.

${ }^{36}$ Davies, S. (2006), p. 190. Alan Goldman also takes the definition-evaluation parallelism to entail that artworks must be of value. See Goldman (2004), p. 93: 'According to one common conception of art, to call something an artwork is already to grant it a positive evaluative status. What counts as a genuine work of art must meet some minimum standard of artistic value, so that minor or mediocre works of art are still better than objects that purport to be works of art but do not merit that status.'
} 
sins. If artistic value is attributive goodness, then an argument would be needed for thinking that the reasoning isn't just as faulty in the art case.

I've argued in this section that if artistic value is attributive goodness, being a valuedefinition and having the definition-evaluation parallelism are not the same thing. Given this, an extremely popular objection to value-definitions is mistaken (it's really an objection to the definition-evaluation parallelism), and a consequence that has been held to follow from the definition-evaluation parallelism in fact doesn't obtain (it's only a consequence of value-definitions).

\section{Conclusion}

I've argued that artistic value is a kind of attributive goodness, and that this has farreaching and important consequences for a number of debates in aesthetics. First, certain theses about artistic value that are often taken for granted - the necessity claim, distinctivism - turn out to have a greater burden of proof than ordinarily appreciated. Second, some popular argumentative moves in debates about the definition of art, realism about artistic value, and artistic empiricism, are fundamentally mistaken.

\section{References}

Beardsley, M. (1981) Aesthetics: Problems in the Philosophy of Criticism (Indianapolis: Hackett)

Bender, J. (2005) 'Aesthetic Realism 2' in Levinson (ed.) Oxford Handbook of Aesthetics (Oxford: OUP) pp. 80-98.

Budd, M. (1995) Values of Art (London: Penguin).

Budd, M. (1980) 'The Repudiation of Emotion: Hanslick on Music', British fournal of Aesthetics 20(1): pp. 29-43.

Conolly \& Haydar (2001) 'Narrative Art and Moral Knowledge' British fournal of Aesthetics 41(2): 109-124.

Davies, D. (2005) 'Against Enlightened Empiricism', in M. Kieran (ed.) Contemporary Debates in Aesthetics and the Philosophy of Art, (Oxford: Blackwell), pp. 22-34.

Davies, S (2006) Foundations of the Philosophy of Art (Blackwell)

Davies, S. (2007) Philosophical Perspectives on Art (OUP). 
Dickie, G. (1989) Evaluating Art (Temple University Press).

Dickie, G. (2000) 'Two Versions of the Institutional Theory,' in N. Carroll (Ed.) Theories of Art Today (University of Wisconsin Press), pp. 93-108.

Dodd, J. (2014) 'On a Proposed Test for Artistic Value' British fournal of Aesthetics 54(4): 395-407.

Eldridge, R. (2014) An Introduction to the Philosophy of Art (Cambridge: Cambridge University Press).

Fenner, D. (2004) 'Artistic Value' Fournal of Value Inquiry 37:555-563.

Gaut, B. (2007) Art, Emotion, and Ethics (Oxford: OUP).

Geach, P. (1956) 'Good and Evil' Analysis 17(2): 33-42.

Goldman, A. (2004) 'Evaluating Art' in P. Kivy (Ed.) Blackwell Guide to Aesthetics (Oxford: Blackwell), pp. 93-108.

Goldman, A. (1998) Aesthetic Value (Boulder, CO: Westview Press)

Goldman, A. (1993) 'Realism about Aesthetic Properties' Journal of Aesthetics and Art Criticism 51(1): 31-37.

Graham, G. (1997) Philosophy of the Arts, (London: Routledge)

Graham, G. (2006) 'Aesthetic Empiricism and the Challenge of Fakes and Readymades' in Kieran (Ed.) Contemporary Debates in Aesthetics and the Philosophy of Art (Oxford: Blackwell), pp. 11-21.

Grant J. 'Being Valuable and Being Good' [unpublished manuscript].

Haskins, C. (2000) 'Paradoxes of Autonomy' Journal of Aesthetics and Art Criticism 58(1): $1-22$.

Huddleston, A. (2012) 'In Defense of Artistic Value' Philosophical Quarterly 62(249): 705-714.

Iseminger, G. (2004) The Aesthetic Function of Art (Ithaca: Cornell UP)

Kagan, S. (1998) 'Rethinking Intrinsic Value' Journal of Ethics 2(4): 277-297.

Kieran, M. (2013) 'Value of Art' in B. Gaut \& D. Lopes (eds.) Routledge Companion to Aesthetics (Routledge), pp. 290-296.

Korsgaard, K. (1983) 'Two Distinctions in Goodness' Philosophical Review 92(2): 169-195. 
Levinson, J. (1992) 'Pleasure and the Value of Works of Art' British Fournal of Aesthetics 32(4): 295-306.

Lopes, D. (2011) 'The Myth of (Non-Aesthetic) Artistic Value' Philosophical Quarterly 61(244): 518-536.

McGregor, R. (2014) 'A Critique of the Value Interaction Debate' British Fournal of Aesthetics 54(4): 449-466.

Pratt. H. (2012a) 'Artistic Institutions, Valuable Experiences: Coming to Terms with Artistic Value' Philosophia 40(3): 591-606.

Pratt, H. (2012b) 'Respect, Recognition, and Appraisal: Are All Artworks Valuable' Journal of Value Inquiry 46: 157-158.

Railton, P. (1998) 'Aesthetic Value, Moral Value, and the Ambitions of Naturalism', in Levinson (ed.) Aesthetics and Ethics (Cambridge: Cambridge University Press) pp. 59105.

Sharpe, R. (2000) 'The Empiricist Theory of Artistic Value' Journal of Aesthetics and Art Criticism 58: 321-32.

Shelley, J. (2003) 'The Problem of Non-Perceptual Art' British fournal of Aesthetics 43(4): 363-378.

Shelley, J. (2010) 'Against Value Empiricism in Aesthetics', Australasian Fournal of Philosophy 88: 707-10.

Stang, N. (2012) 'Artworks are Not Valuable for Their Own Sake' Journal of Aesthetics and Art Criticism pp. 271-280.

Stecker, R. (1997a) Artworks: Definition, Meaning and Value (University Park, PA: Pennsylvania State University Press).

Stecker, R. (2005) 'Value in Art' in Levinson (ed.) Oxford Handbook of Aesthetics (OUP) pp. 307-324.

Stecker, R. (2013) 'Testing Artistic Value: A Reply to Dodd' Fournal of Aesthetics and Art Criticism 71 (3):288-289.

Stecker, R. (1997b) 'Two Conceptions of Artistic Value’ Iyyun 46: 51-62.

Stecker, R. (2012) 'Artistic Value Defended' Journal of Aesthetics and Art Criticism 70(4): 355-362.

Thomson, J. (2008) Normativity (Peru, IL: Open Court). 
Wieand, J. (1981) 'Quality in Art' British fournal of Aesthetics: 21(4): 330-335. 